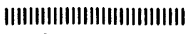

論 文

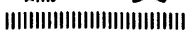

\title{
服装の好感度に対する単純接触の効果
}

$\begin{array}{lllll}\text { 共立女子大学家政学部 } & \text { 長 } & \text { 田 } & \text { 美 } & \text { 穂 (会員) } \\ \text { 共立女子大学家政学部 } & \text { 杉 } & \text { 山 } & \text { 真 } & \text { 理 (会員) } \\ \text { 共立女子大学家政学部 } & \text { 小 } & \text { 林 } & \text { 茂 } & \text { 雄 (会員) }\end{array}$

\section{Effect of Mere Exposure on Favorability Impression for Dress}

\author{
Miho Osada, Mari Sugiyama and Shigeo Kobayashi \\ Faculty of Home Economics, Kyoritsu Women's University \\ Hitotsubashi, Chiyoda-ku, Tokyo
}

\begin{abstract}
The hypothesis has been offered that mere repeated exposure of stimulus object makes a favorable impression. It is the purpose of this paper to discuss whether the effect of mere exposure appears in the case of impressions for dresses. In this experiment, fourteen photographs of novel dresses were used as stimulus objects, and they were rated by means of 12 semantic differential scales which contain favorable impression scales such as "agreeable-disagreeable", "friendly-unfriendly" and "likable-dislikable". In regard to the rating experimtnts, the scale values of "friendly-unfriendly" and "likable-dislikable" except on "agreeable-disagreeable" moved towards favorable scale side with increasing the number of stimulus exposures.

From the result of this study, it became clear that the effect of mere exposure appears as numbers of stimulus exposures approaches about 20 times over 10 times at least. It is considered that the effect of mere exposure for dress is related to one reason of adoptable motives in fashion.

(Received May 7, 1992)

(Accepted for Publication October 7, 1992)

\section{摘 要}

目的 刺激対象を見慣れれば，その刺激対象に好感を抱くようになるという単純接触の効果が, 服装の印象の場合についても 成り立つかどうかを検討することを目的とする。

成果 新奇な服装図版を刺激対象とした実験を通して,「親しみやすい一親しみにくい」,「好きな一嫌いな」の尺度には, 刺激の 1 回呈示条件ないし10回呈示条件よりあ20回呈示条件において好感度が高くなり, 単純接触の効果が現われた。しかしながら, 「感じのよい一感じのわるい,の尺度には，単純接触の効果は現われなかった。

これらのことから服装の場合, 呈示回数が少なくとも10回を超えて20回近くになれば, 単純接触の効果がはっきりと現われる ことが明らかになった．このように，ただ単に何回も目にするだけで服装に対する好感度が高まってくることは, 服装の流行の 採用動機の一つとして, 単純接触の効果が関与していることが考えられる.

(平成 4 年 5 月 7 日受理) (平成 4 年10月 7 日審査終了)

\section{1. 緒 言}

刺激対象を見慣れれば，その刺激対象に好感を抱 くようになるという単純接触仮説を R. B. Zajonc ${ }^{1)}$ は提唱した。すすなお，彼は人物写真や単語（漢字 ・無意味つずり）を刺激対象として，刺激を繰り返
し呈示し好感度の変化を実験している．この実験を 通して, これらの刺激のいずれの場合についても， 刺激の繰り返し呈示により好感側に評定が変化する ことを明らかにしている，その後，単純接触仮説に 関する研究はいくつかあるが，服装を対象としたも のはない，すなわち, Perlman は2は人物写真を刺 
激対象に用い，また Brickman ら ${ }^{3)}$ は絵画を刺激対 象に用い, 繰り返し呈示により好意を抱くようにな ることを明らかにしている. Mita ら ${ }^{4)}$ は人物の顔写 真をそのまま焼付けたものと，裏返して焼付けた鏡 像のむのとを刺激対象に用いて実験をしている。 そ の結果，写真の当人は日頃，鏡を通して見慣れてい る鏡像の写真を好み, 友人はそのままの写真の顔を 好むという結果を得ている. また, 長田ら ${ }^{5)}$ は Mita らの研究が女性を対象にしたものであるのに対し て, 男女について実験している. その結果, 女性に ついては Mita らと同様の結果が得られ, 男性につ いても友人の判断において女性と同様な結果を得て いる.

本研究では, この単純接触仮説が服装の印象の場 合についても成り立つかどうかを検討することであ る. 服装における流行の採用動機としては, (1)新し さと変化を求める動機, (2)差別化と他者の承認を得 たという動機，(3)同調化と社会に適応しょうという 動機，(4)自我防衛の動機，(5)個性化之自己実現の動 機があげられている6).しかしながら，あし，服装に おいてもこの単純接触仮説が成り立つことが実証さ れれば, 服装の流行採用動機の一つとして, 単純接 触の効果が関与しているという新しい考え方を示す 根拠になるであろう.

\section{2. 実 験 1}

新奇な印象を与える衣服の着用写真を, 時間間隔 をおいて 2 回見せたときに, 1 回目と 2 回目で, 服 装に対する印象がどのように変わってくるかを，好 感度の変化を中心に SD 法によって調べる，併せ て，好感度をとらえる SD 尺度項目として，どのよ
うな項目を用いるのが該当であるかを因子分析によ って明らかにし, また, 取り上げた服装がどの程度 新奇なあのであったかについても検討する.

\section{1 方 法}

ファッション雑誌から新奇と思われる多数の衣服 の着用写真を集め，その中から14枚の図版を選定し た.これらの図版からカラースライド写真を作り刺 激対象とした. 被験者は女子大生 (2 年生) 62名であ り，1991年10月に集合調查法により実施した.

次のような手続きにより実験を進めた。 まず14枚 の図版をスライドで通覧してもらった後, 改めて 1 枚ずっスライドを呈示し，服装から受ける印象を $\mathrm{SD}$ 法 (12形容語対, 7 段階尺度) を用いて評定させ た. 表 1 は SD 法の 12 の形容語対である.これらの 形容語対の尺度には，好感度を測定すると見込まれ る尺度（尺度 $3 ， 6 ， 7$ ）のほ加に，新奇さを測定する 尺度 (尺度 4), さらには研究の目的とは直接関係の ない尺度（その他の尺度で, これらはできるだけ被 験者に実験の意図を感ずかれないためのいわば為装 項目）が含まれている.

1 回目の評定の後, 約20分後に再び同じ順序で刺 激図版をスライドで呈示し，1 回目と同様に SD 法 を用いて評定させた。

\section{2 結黑および考察}

まず，用いた12の尺度のうちで, 好感度を測定し ていると考えられる尺度を確定するために, 第 1 回 目の評定結果を因子分析した.すなわち，12の尺度 を変数に，14枚の刺激図版を観測回数とし，62名の 被験者の平均評定デー夕を用いて因子分析を行っ

Table 112 rating scales measuring impressions of dresses

\begin{tabular}{|c|c|}
\hline scale №. & rating scale \\
\hline 1 & gay（派手な）-plain（地味な） \\
\hline 2 & casual (カジュアルな)-formal（フォーマルな) \\
\hline 3 & agreeable (感じのよい)-disagreeable（感じのわるい） \\
\hline com & mmonplace (ありふれた)-novel (珍しい) \\
\hline 5 & modern (モダンな)-classic (クラッシックな) \\
\hline 6 & friendly（親しみやすい)-unfriendly（親しみにくい） \\
\hline 7 & likable (好きな)-dislikable（嫌いな） \\
\hline 8 & mature (大人っぽい)-childish (子供っぽい) \\
\hline 9 & manly (男っぽい)-womanly (女っぽい) \\
\hline 10 & progressive（進歩的な）-conservative（保守的な） \\
\hline 11 & sporty（スポーティな）-dressy（ドレッシィな） \\
\hline 12 & conspicuous (人目をひく)-quiet（人目をひかない） \\
\hline
\end{tabular}


Table 2 Factor analysis of impression ratings

\begin{tabular}{c|r|r|r|l}
\hline \hline scale No. & Factor 1 & Factor 2 & Factor 3 & $h^{2} *$ \\
\hline 1 & -0.120 & 0.071 & 0.926 & 0.876 \\
2 & -0.005 & 0.932 & 0.144 & 0.889 \\
3 & 0.893 & -0.009 & -0.315 & 0.897 \\
4 & 0.676 & -0.169 & -0.518 & 0.754 \\
5 & -0.485 & 0.238 & 0.786 & 0.909 \\
6 & 0.918 & 0.076 & -0.343 & 0.966 \\
7 & 0.914 & -0.278 & -0.178 & 0.944 \\
8 & -0.116 & -0.917 & 0.111 & 0.867 \\
9 & -0.457 & 0.775 & 0.032 & 0.810 \\
10 & -0.602 & -0.017 & 0.747 & 0.921 \\
11 & -0.115 & 0.894 & 0.203 & 0.854 \\
12 & 0.601 & 0.012 & 0.762 & 0.942 \\
\hline
\end{tabular}

\section{Contribu-}

tion (\%)

34.5

27.4

26.7

$* h^{2}$ is communality

Table 3 Mean and standard deviation of novelty impression rating for each dress

\begin{tabular}{c|c|c}
\hline \hline Dress & Mean & $S D$ \\
\hline A & 5.55 & 1.20 \\
B & 5.52 & 1.19 \\
C & 6.32 & 0.93 \\
D & 3.73 & 1.22 \\
E & 5.76 & 1.07 \\
F & 6.74 & 0.59 \\
G & 5.03 & 1.20 \\
H & 4.15 & 1.31 \\
I & 6.47 & 1.09 \\
J & 5.40 & 1.25 \\
K & 4.03 & 1.38 \\
L & 5.23 & 1.60 \\
M & 5.45 & 1.21 \\
N & 5.79 & 1.47 \\
\hline
\end{tabular}

た。

表 2 は固有值 1.0 以上, バリマックス回転後の因 子負荷量を示したあのである. 表に示すように 3 因 子が抽出されたが，これらの因子のうち，第 1 因子 が好感度因子と命名されるものであり, 尺度として は「感じのよい一感じのわるい」(尺度 3 ),「親しみや すい一親しみにくい」(尺度 6),「好きな一嫌いな」(尺 度 7) が該当している. 従って, 本研究においては好 感度を測定する尺度として，これら 3 尺度を用いる ことにした。

次に用いた刺激図版の服装がどの程度の新奇さを
持ったものであるかを，第 1 回目の評定結果からみ てみる．表 3 は，14枚の図版のそれぞれに対する 「珍しいーありふれた」の評定の平均値と標準偏差で ある. 平均値が大きいほど新奇なすのと受けとめら れていることを示している．図版 D 以外は，いずれ 6平均值が「珍しい」の側に位置（中立点 4.00）し ており，新奇なものを取り上げようとする本研究の 要件は達成されているといってよい.

これらの14枚の図版の中から図 1 に示す 3 枚の図 版を選んで，第 2 回目の評定で好感度がどのように 变わったかをみてみる. 3 枚の図版として選んだの は, 表 3 の評定結果において， 2 番目， 4 番目， 5 番 目にそれぞれ新奇であるとされた図版 I，N，Eであ る. 表 4 は，3図版のそれぞれの好感度に関する各 回の評定の平均值である. いずれす平均値が大きい ほど, 好感度が高いことを示している.この第 1 回 目と第 2 回目の平均値間に, 統計的な有意差が認め られるかどうかをみるために $t$ 検定（対応のある場 合の平均値の差の検定）を行ったが, その結果も示 した.

$t$ 検定の結果, 尺度 3 (「感じのよい一感じのわる い」)では, 有意な結果は 3 図版のいずれにおいてす 得られていない. 有意な結果が得られているのは, 尺度 6 (「親しみやすい一親しみにくい」)では図版 I においてのみ，また尺度 7 (「好きな一嫌いな」）では 図版 N においてのみである. 結局, 実験 1 の結果か らは，単純接触仮説を支持する結果が得られたとい ってあ，極めて限られた部分的なものである．すな わち，図版や尺度によってかなりまちまちな結果が 出ていて, 全体的にみて単純接触の効果が現われた とはいえない．このように単純接触の効果が十分に 現われなかったのは, 実験 1 に予備実験的な意味あ いを持たせたことああって，呈示回数をわずか 2 回 （最初に通覧してあらったのを含めても 3 回）にと どめていたことによるものと考えられる。ちなみに Zajonc $^{1)}$ は，刺激を10回，さらに25回む呈示する実 験を行って効果を見い出しているので, 呈示回数を あっと増やすことを考える必要がある.

\section{3 . 実 験 2}

実験 1 に引き続いて，新奇な服装を何回も目にす るうちに，その服装に好感を抱くようになるかどう かを検討する. 実験 1 の結果を踏まえて, 呈示回数 を大幅に増やして実験する，具体的には，1回と10 回と20回の各呈示条件による好感度の違いを比較検 


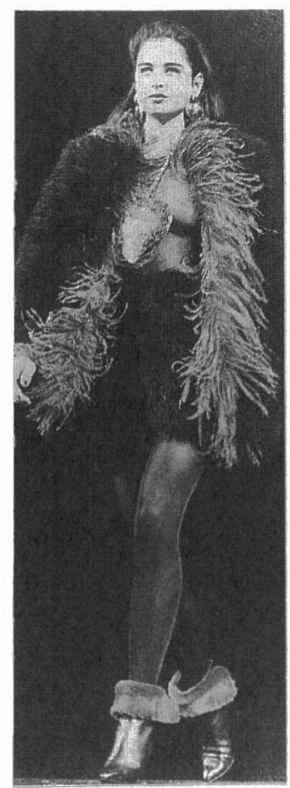

D ress E
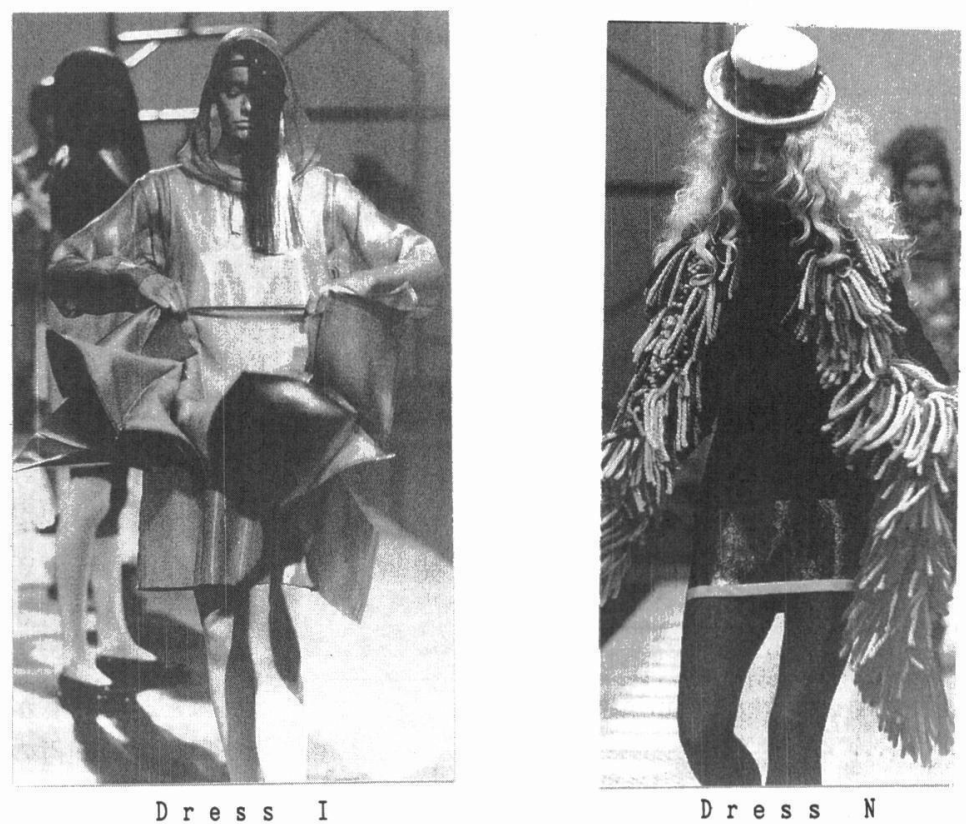

Fig. 1 Photos of dress E, I and N.

Dress $\mathrm{E}, \mathrm{I}$ and $\mathrm{N}$ reproduced from RYUKO-

TSUSHIN (No. 7, No. 8, 1991)

Table 4 Means of favorability impression ratings for Dress $\mathrm{E}, \mathrm{I}$, and $\mathrm{N}$

\begin{tabular}{ccccc}
\hline \hline Dress & Scale & 1st rating & 2nd rating & $t$ \\
\hline \multirow{4}{*}{ E } & 3 & $3.08(1.22)$ & $3.32(1.45)$ & 1.59 \\
& 6 & $2.76(1.34)$ & $2.87(1.30)$ & 0.82 \\
& 7 & $2.98(1.41)$ & $3.21(1.54)$ & 1.78 \\
& Total & $8.82(3.71)$ & $9.40(3.95)$ & 1.80 \\
\hline & 3 & $3.32(1.13)$ & $3.19(1.01)$ & -1.02 \\
I & 6 & $2.42(1.19)$ & $3.07(1.47)$ & $3.64^{* *}$ \\
& 7 & $3.29(1.51)$ & $3.11(1.33)$ & -0.79 \\
& Total & $9.03(3.16)$ & $9.37(3.05)$ & 1.05 \\
- & 3 & $3.26(1.50)$ & $3.48(1.43)$ & 1.48 \\
\multirow{4}{*}{ N } & 6 & $3.03(1.55)$ & $3.07(1.56)$ & 0.24 \\
& 7 & $3.03(1.44)$ & $3.36(1.64)$ & $2.42^{*}$ \\
& Total & $9.32(4.23)$ & $9.90(4.33)$ & 1.78 \\
\hline
\end{tabular}

Values in parentheses indicate standard deviations.

${ }^{*} p<.05 \quad{ }^{* *} p<.01$

討する.

\section{1 方 法}

実験 1 の結果を踏まえて, 呈示回数を大幅に増や
して実験した. すなわち, 呈示回数は 1 回, 10回, 20 回の 3 条件とした。刺激には実験 1 で用いたと同 じ14枚の図版（図版 $\mathrm{A} \sim \mathrm{N}$ ) を, $15 \mathrm{~cm} \times 10 \mathrm{~cm}$ の大 きさのカラー写真にしたものを用いた。 これらのう ち実際に呈示条件を操作する図版は実験 1 で考察の 対象とした図版 $\mathrm{E}, \mathrm{I}, \mathrm{N}$ の 3 図版である.

実験は個別実験であり，図版 $\mathrm{E}, \mathrm{I}, \mathrm{N}$ のうち，1 図版については20枚, あう1図版については10枚, 残りのもう 1 図版については 1 枚, そして 3 図版以 外については各 1 枚の, 合計 42 枚の写真をランダム に綴ったものが, 1 人の被験者に呈示された.この 場合, 被験者によって, 3 図版のどれを 20 枚にし, ど れを10枚にし，どれを 1 枚にするかを変えた。すすな わち, 被験者を 6 群に大別し, 表 5 に示すように配 置して, 図版による影響を相殺するようにした。 こ れは実験 1 で, 図版によってかなり異なった結果が 見い出されたことによる.

被験者は20代を中心にした社会人（男性 4 名, 女 性15名), および大学生 (男性16名, 女性27名) の合 計62名を対象に実験を行った。この場合, 表 5 に示 す 6 グループはそれぞれ10名 (男性 3 名, 女性 7 名) 
Table 5 Allocation of subjects' groups to combinations of three exposure conditions

\begin{tabular}{cccc}
\hline \hline Group & Dress E & Dress I & Dress N \\
\hline I & 2 2exposures & 10 & 1 \\
II & 20 & 1 & 10 \\
III & 10 & 20 & 1 \\
IV & 10 & 1 & 20 \\
V & 1 & 20 & 10 \\
VI & 1 & 10 & 20 \\
\hline
\end{tabular}

Each group consists of 10 subjects

あるいは11名（男性 4 名，女性 7 名）により構成さ れている。 そこで各グループが男性 3 名, 女性 7 名 で等しくなるようにするため, 11名のグループにつ いては無作為に男性 1 名ずつを除外したので, 実際 の被験者は60名である.

次のような実験の手続きにより実験を進めた。実 験は個別に行い，まず被験者に14枚の写真を通覧さ せた上で, 順に 1 枚ずつ呈示して，それぞれの服装 から受ける印象を SD 評定尺度上に評定させた。 な お, 評定用紙は実験 1 と同様のあのである. 次に, 42枚の写真の経りから，1枚ずつ取り出して被験者 に呈示し，順にゆっくりと見てあらった. 最後に, 図版 $\mathrm{E}, \mathrm{I}, \mathrm{N}$ の 3 枚についてのみ, 再び第 1 回目之 同様の評定をさせた.

\section{2 結果および考察}

用いた 3 図版（図版 $\mathrm{E}, I ， \mathrm{~N}$ ) の持つ新奇さが, 実験 2 の被験者にとってあ確かに新奇なものであっ たか, また14図版の中で 3 図版のそれぞれの新奇さ がどのような位置を占めているのかを，第 1 回目の 評定結果をむとにみてみる. 表 6 に示すように，実 験 1 の場合よりあ新奇さの程度が相対的に低下して いるが，3図版は明らかに新奇な側に位置（中立点 は4.00）しているといえる. また，14図版の中での 3 図版の新奇さの相対的な位置関係む実験 1 の場合 とほぼ同様である. 実験 1 と比べて新奇さの程度が 相対的に低いのは, 実験 1 の被験者が大学 2 年の女 子大生のみであったのに対して, 実験 2 の被験者に は社会人や男性が含まれていることが関係している のかもしれない.

次に, 呈示条件ごとの好感度に関する結果をみて みる．この実験では，実験 1 の結果を踏まえて図版 の違いによる影響を相殺する方法を用いているので (表 5 参照), 好感度に関する結果は, 3 図版全体と
Table 6 Mean and standard deviation of novelty impression rating for each dress in Experiment 2

\begin{tabular}{c|c|c}
\hline \hline Dress & Mean & $S D$ \\
\hline A & 5.17 & 1.37 \\
B & 5.25 & 1.23 \\
C & 4.95 & 1.69 \\
D & 3.82 & 1.44 \\
E & 5.03 & 1.28 \\
F & 6.45 & 1.13 \\
G & 4.28 & 1.28 \\
H & 4.38 & 1.24 \\
I & 5.90 & 1.01 \\
J & 4.40 & 1.39 \\
K & 3.13 & 1.01 \\
L & 3.97 & 1.33 \\
M & 5.47 & 1.63 \\
N & 5.05 & 1.38 \\
\hline
\end{tabular}

してみていくことにする．表 7 はその結果であり, 各呈示条件ごとの平均值を示したものである，この 三つの呈示条件の平均値間に，統計的な有意差が認 められるかどうかをみるために $F$ 検定を行ったが, その結果も示した，尺度 3 (「感じのよい一感じのわ るい」）を除いて，尺度 6 (「親しみやすい一親しみに くい」), 尺度 7 (「好きな一嫌いな」), および 3 尺度全 体において，いずれす $1 \%$ 水準で有意差が認められ る.

この結果は単純接触仮説を支持するあのである が, 具体的によ゙の呈示条件とどの呈示条件の間に有 意差が認められるかを, 尺度 6 , 尺度 7,3 尺度全体 の場合について多重比較 (Ryan 法)により調べた. その結果, 尺度 6 では 1 回呈示と 20 回呈示間, およ び10回呈示と20回呈示間にいずれす 5\%水準で有意 差が認められた。 また, 尺度 7 では 1 回呈示と 20 回 呈示間および10回呈示と20回呈示間にいずれす $1 \%$ 水準で有意差が認められた. 3 尺度全体についてあ, 尺度 6 と尺度 7 の場合とほぼ同様の結果になってい る. すなわち, 1 回呈示条件と10回呈示条件間を除 いて, 1 回呈示と 20 回呈示間, および10回呈示と 20 回呈示間にいずれも $5 \%$ 水準で有意差が認められ る.

ところで 1 回呈示条件の評定は, 実験 1 の第 2 回 目の評定に当たる. 実験 1 において第 1 回目と第 2 回目の評定間に, 単純接触仮説を支持する明確な結 果は得られていないので, 結局, 単純接触仮説の効 果は, 呈示回数が少なくとも10回を超えて, 20回近 
Table 7 Means of favorability impression ratings in tree experimental conditions

\begin{tabular}{ccccc}
\hline \hline Scale & 1 exposure & 10 exposures & 20 exposures & $F$ \\
\hline \multirow{2}{*}{3} & 3.83 & 4.13 & 4.33 & 2.00 \\
& $(1.50)$ & $(1.36)$ & $(1.31)$ & \\
6 & 3.87 & 4.22 & 4.68 & $5.56^{* *}$ \\
$\cdot$ & $(1.51)$ & $(1.32)$ & $(1.36)$ & \\
7 & 3.87 & 4.13 & 4.92 & $9.78^{* *}$ \\
& $(1.58)$ & $(1.36)$ & $(1.41)$ & \\
Total & 11.57 & 12.48 & 13.93 & $6.00^{* *}$ \\
& 4.39 & $(3.71)$ & $(3.74)$ & \\
\hline
\end{tabular}

Values in parentheses indicate standard deviations ${ }^{* *} p<.01$

くにならないと顕著に現われてこないといえるよう である．いずれにしてと実験 2 の結果から，刺激が 服装の場合にも単純接触仮説の効果が表われてくる ことが明らかにされた。

\section{4. 総合的考察}

単純接触仮説が服装の面であ実証されるかどうか を検討するために，実験 1 と実験 2 の二つの実験を 行った.この場合, 実験 1 は実験 2 の予備実験的な 意味あいをあつあのであった. 実験 2 の結果から, 単純接触仮説が服装についても成立つことが明らか にされた。すすなわち，1回呈示条件ないし10回呈示 条件よりあ20回呈示条件において, 好感度が高いと いう結果が得られた.

服装における流行の採用動機は，緒者に記述した ように次の五つに大別されている，それらは，(1)新 しさと変化を求める動機，(2)差別化と他者の承認を 得たいという動機，(3)同調化と社会に適用しょうと いう動機，(4)自我防衛の動機，(5)個性化と自己実現 の動機である.これらの動機にもあげられているよ うに, 流行の採用動機は他者の行為を模做し集団や 社会に順応しようとする「同調化への欲求」と, 新 しい様式を採用し他者と区別したいと願う「差別化 や変化への欲求」との関係としてとらえられてい る. しかしながら, 服装について単純接触仮説が成 り立つことは, 服装の流行採用の動機の一つとし て，「見慣れているうちに好ましく感じるようにな ったので着用したい」という動機（理由）を追加す ることが必要であると思われる.

本研究の結果, 出てきた課題あるいは残された課 題はいくつかある. 例えば, 本研究では好感度を測 定する尺度として,「感じのよい一感じよわるい」,
「親しみやすい一親しみにくい」,「好きな一嫌いな」の 3 尺度を用いたが，3 尺度ごとの評定結果をみると 尺度による違いがみられる，違いが考えられたから こそ，複数の尺度を用いないと好感度の十分な測定 は期待できなく，そこで因子分析で同じ因子に負荷 量の大きかった 3 尺度を用いたわけである. しかし ながら問題は，好感度がいくつかの側面から成立っ ているのではないか, そして単純接触の効果はその うちのどの側面に敏感に反応するのだろうか，とい う問題が出てきたことである.

本研究の結果からみると, 単純接触の効果は「好 きな一嫌いな」と「親しみやすい一親しみにくい」の 尺度には現われるが,「感じのよい一感じのわるい」 の尺度には現われていない，この問題は今後の検討 課題であるが一つ考えられることは，「感じのよい一 感じのわるい」の評定には人々が一般にどう思うか という, 他人の判断の意識が伴うのに対して,「好き な一嫌いな」の評定では，他人がどう思おうと自分が 気に入っているかどうかという個人的な好みの問題 として評定している，という違いがあるのではない だろうか. いずれにしても，好感度の持つ側面およ びその側面と単純接触の効果との関連は, 今後の重 要な課題であろう.

また，そもそも単純接触の効果はどうして生じる かという問題がある。これこそ追求しなければなら ない大きな問題である. Zajonc は単純接触の効果 を，単に接触するだけで生ずる効果であるとして， このような名称を与えたのであるが，どうしてこの ような効果が生じるのかについては，まだ明確な定 説はない. 


\section{5. 結 言}

本研究の目的は刺激対象を見慣れれば, その刺激 対象に好感を抱くようになるという単純接触仮説 が，服装においても成り立つかどうかを検討するこ とであった。このために二つの実験（実験 1 と実験 2) を行った. 実験 1 は実験 2 の予備実験的な意味あ いを持ったものであり, 用いた刺激図版の新奇さの 程度，好感度をとらえるための SD 用語の妥当性, 単純接触の効果に対する刺激の呈示回数などについ て検討した。

次に, 実験 1 の結果をあとに実験 2 では, 3 刺激 図版（図版 E，I，N）に注目し呈示回数を20回まで に增やして，服装に対する好感度の測定を行った。 この場合, 好感度の尺度としては, 「感じのよい-感 じのわるい」,「親しみやすい一親しみにくい」,「好き な一嫌いな」の 3 尺度を用いた. 実験 2 の結果から, 「親しみやすい一親しみにくい」と「好きな一嫌いな」 の尺度には, 刺激の 1 回呈示条件ないし10回呈示条 件よりあ20回呈示条件において好感度が高くなり, 単純接触の効果が現われた. しかしながら,「感じの よい一感のわるい」の尺度には, 単純接触の効果は現 われなかった。

呈示回数が少なくとも10回を超えて 20 回近くにな
れば, 単純接触の効果がはっきりと現われることが 明らかになった。このように，ただ単に何回む目に するだけで服装に対する好感度が高まってくること は, 服装の流行の採用動機の一つとして, 単純接触 の効果が関与していることが考えられる.

本研究を進めるに当たり，ご助言を受けた名古屋 大学教授長田雅喜氏に感謝申し上げる. なお, 本研 究の大要は, 「日本㵶維機械学会被服心理学研究分 科会研究発表会」(平成 4 年 3 月名古屋) および「日 本織維機械学会年次大会」(平成 4 年 6 月大阪) で発 表した。

\section{参考文献}

1) R. B. Zajonc; Journal of Personality and Social Psychology Monograph Supplement, 9, 1 (1968)

2) D. Perlman, S. Oskamp; Journal of Experimental Social Psychology, 7, 503 (1971)

3) P. Brickman, J. Redfield, A Harrison, R. Crandall ; Journal of Experimental Social Psychology, 8, 31 (1972)

4) T. H. Mita, M. Dermer, J. Knoght; Journal of Personality and Social Psychology, 35, 597 (1977)

5）長田雅喜, 伊藤義美, 舟橋厚; 名古屋大学教養部紀要 B, 32, 101 (1988)

6）日本織機学会被服心理学研究分科会編; “被服心理学”, p. 134, 日本紻機学会 (1988) 